\title{
Improving Government to Employee (G2E) Services through Mobile Technology - A Survey
}

\author{
Velamala Ranga Rao \\ Senior System Analyst \\ Soil and Land Use Survey of India \\ Department of Agriculture, Cooperation and Farmers Welfare \\ Ministry of Agriculture and Farmers Welfare, Government of India
}

\begin{abstract}
This paper objective is a) To propose Mobile based Government to Employee (MG2E) services b) To investigate the adoption of MG2E services in the Indian government departments as a case study and c) To identify problems associated with these services. In order to identify the adoption of the proposed MG2E services, a questionnaire was developed fifteen MG2E services after elaborate discussions with the government employees. A survey was conducted on hundred employees from the study area of fifty government departments and its autonomous institutions from four State and twenty-three Central government departments to find out the implementation of proposed MG2E services by these departments. The survey data was analyzed and found that most of the MG2E services are not yet implemented in many government departments in India although some services provided through SMS notifications. This study shows that every employee owned mobile device and charges paid by them. Therefore, the government should use this opportunity and introduce MG2E services to get benefits by both employees and government. This study may give a better understanding to the decision makers and researchers in the MG2E service area.
\end{abstract}

\section{General Terms}

E-Government, Mobile Government, E-Services

\section{Keywords}

E-Government, Employee Services, G2E, ICT, Mobile Government, Mobility, Mobile applications, SMS

\section{INTRODUCTION}

The goal of electronic government (E-Government) is to offer services to their employees and citizens in a transparent and efficient way. The employees and citizens are different needs and hence the government should offer their services through multiple channels according to the citizen satisfaction. Providing government services through the mobile channel are an important issue in developing country particularly in India due to the high penetration of mobile devices and decreasing the cost of Internet charges (Ghyasi and Kushchu, 2004). Many governments across the world, including developing countries like India, recognized services using mobile devices, for an example law enforcement agency of the United States of America (USA) using mobile based services for mission-critical applications from the field (Black Berry, 2014). According to (UN, 2012), sixty countries are providing mobile based services. According to CISCO (2013), the number of mobile devices will be more than the population of the world by the year 2017 and it can expect more than 10 billion mobile devices (CISCO, 2013). A survey by IAMAI (2015) projected that in India, the number of mobile Internet users may increase from the present 159 million to 300 million by the end of the year 2017 .

This paper divided into six sections. The literature review related to the Government to Employees (G2E) services, transforming E-Government to M-Government given in Section-2. In Section-3, proposed Mobile based Government to Employee (MG2E) services classification and its benefits are discussed. A case study, research methodology, results \& findings were given in Section-4. Issues and challenges related to MG2E services mentioned in the Section-5.Section6 and Section-7 concluded with recommendations and conclusions.

\section{LITERATURE REVIEW}

This section reviewed the literature on E-Government to MGovernment related to the Government to Employees (G2E) services.

\subsection{Concepts and Motivation}

Many government departments across the world are providing services to the citizens using multichannel service delivery. According to the Oui-Suk, Uhm (2010), the evolution of government is classified into three categories namely a) Conventional Government (C-Government) to enforce national policies, as well as the mechanism for determining policies b) Electronic Government (E-Government) used to providing services electronically by utilizing the Information and Communication Technologies (ICT), particularly Internet and c) Mobile Government (M-Government), for providing public service delivery through mobile technologies. An overview of Conventional, Electronic and mobile government is given in Table 1 .

Table 1: An overview of concepts of Conventional, Electronic and mobile government [Source:Oui-Suk (2010)].

\begin{tabular}{|l|l|l|l|}
\hline Item & c-Government & E-Government & m-Government \\
\hline Principles & $\begin{array}{l}\text { Bureaucratic } \\
\text { Process }\end{array}$ & $\begin{array}{l}\text { Process re- } \\
\text { engineering } \\
\text { using ICT }\end{array}$ & $\begin{array}{l}\text { Seamless } \\
\text { Integration } \\
\text { and linkage }\end{array}$ \\
\cline { 2 - 5 } & $\begin{array}{l}\text { Face-to- } \\
\text { Face, Phone } \\
\text { and Fax }\end{array}$ & $\begin{array}{l}\text { Internet and } \\
\text { PC }\end{array}$ & $\begin{array}{l}\text { Mobile } \\
\text { /Wireless } \\
\text { Devices }\end{array}$ \\
\hline $\begin{array}{l}\text { Service } \\
\text { time }\end{array}$ & $\begin{array}{l}\text { Working } \\
\text { hours }\end{array}$ & $\begin{array}{l}\text { 24 hours a } \\
\text { day }, 7 \text { days } \\
\text { a week }\end{array}$ & Any time \\
\hline
\end{tabular}




\begin{tabular}{|l|l|l|l|}
\hline $\begin{array}{l}\text { Service } \\
\text { space }\end{array}$ & $\begin{array}{l}\text { Person visit, } \\
\text { fax ,phone }\end{array}$ & $\begin{array}{l}\text { Citizens } \\
\text { home and } \\
\text { office using } \\
\text { Internet }\end{array}$ & $\begin{array}{l}\text { Citizens } \\
\text { location }\end{array}$ \\
\hline $\begin{array}{l}\text { Service } \\
\text { from }\end{array}$ & $\begin{array}{l}\text { Visits to } \\
\text { Offices }\end{array}$ & Web portals & $\begin{array}{l}\text { Services can } \\
\text { access } \\
\text { through } \\
\text { mobile } \\
\text { devices. }\end{array}$ \\
\hline
\end{tabular}

\subsubsection{E-Government}

The E-Government is also called Electronic Government refers to the use of ICT particularly web-based Internet applications are to improve efficiency, accountability, and transparency of the services of the government (World Bank, 2011). Across the world, many government departments are utilizing the ICT to improve service delivery to the citizens, employees, and business (Choudrie, J., and Dwivedi, Y., 2005.; Mofleh, S., and Wanous, M., 2008). According to the United Nations E-Government Survey (2016), India rank is 107 in the E-Government Development Index (EGDI).

There are four types of government relationships, namely: a) Government-to-Citizen (G2C) to focus on making information accessible to citizens b) Government-to-Government (G2G) to provide services to government departments through intergovernmental relations c) Government-to-Employee (G2E) to focus on relationships between government and employees to coordinate internal operations and improve the internal efficiency d) Government-to-Business (G2B) to facilitate government interactions with the private sector to procure goods and services (Kim et al. ,2004; Amailef \& Lu ,2008; ITU, 2008; Heeks 2013;). In this paper, the study is limited to the Government to Employees (G2E) services.

\subsubsection{Government to Employees (G2E)}

The Government to Employees (G2E) services can be used to share and access information such as policies, training (Tang et al., 2011). The G2E services not only increase management of internal communications, automation, procurement, recruitment, etc. (Michael, 2012) but also improve efficiency, accountability, and quality of services (ITU and OECD, 2011; Golubeva and Merkuryeva (2006)). However, there is a little research done in G2E services area and not widely studied (Hans, 2015; Ho et al., 2005; Markellou et al., 2007). The frameworks of theoretical G2E services provided by the government departments are not clear and research related to G2E services are at the beginning stage (Alvydas Baležentis and Gintare Paražinskaite ,2012). The research on G2E services is very much-needed to study various issues related to the human resource management in the public sector (Ruel et al., 2004). Rao (2011) discussed a need for collaborative $\mathrm{G} 2 \mathrm{E}$ services and their issues and challenges.

\subsubsection{E-Government to M-Government}

Across the globe, there is a rapid growth in the penetration of mobile devices and emergence of mobile applications compared to the traditional wired Personal Computer (PC). Many governments are taking advantage of the rapid growth of wireless technology to provide real-time and locationbased services to the citizens through mobile devices to enhance the quality of services. (Albesher, A.S. and Stone, R.T., 2016; Faisal and Faisal ,2016;Hassan,M., Jaber,T. Hamdan, Z. ,2009; Antovski, L. and Gusev, M. ,2005, MCIT,2009;Al- khamayseh, S., Lawrence, E., and
Zmijewska, A. ,2006;). The main factors of the emergence of M-Government technologies are: a) wider acceptance of these technologies by the public sector b) M-Government services are cheaper than computer-based services c) Increase of penetration of mobile devices d) Ease of use for citizens e) Easier interoperability (ITU, OECD; 2011).Mobile government (M-Government) can be seen as a subset of EGovernment for the use of mobile and wireless communication technology to the delivery of services and information (Amailef and Lu, 2011, Antovski \& Gu-sev, 2005;Kushchu \& Kuscu, 2003).In the mobile government, the services may bring in an effective and transparent way as mobile or portable devices have facilities such as anywhere, anytime, Internet access, text, voice calling mobility, location-based and personal level identity (Ghyasi and Kushchu, 2004; Hans, 2015; Mahatanankoon, et al., 2006; Townsend, 2002; UN, 2014; WB, 2012).

The aim of the M-Government is not intended to eliminate or replace the existing online and offline services. The MGovernment should be considered complementary to the existing E-Government and it should not be considered an alternative to E-Government, for an example the EGovernment is to provide services through wired network with interactive and online web applications, but whereas MGovernment applications support mobility of the citizens and internal operations of the governments, for an example mobile technology may enable mobility of the government employees with ability to handle real-time information and location based services using mobile devices (Ishmatova and Obi, 2009; Kushchu and Kuscu,2003). A survey finds that mobile devices increase in decision making and productivity (FCW, 2012). The social and economic benefits will be higher in rural areas using mobile technologies that now have fewer telephony services (Asheeta, 2008). Due to the high penetration of mobile technologies and mobile devices the use of MGovernment has been increasing rapidly (Albesher A.S. and Stone R.T., 2016; Alrazooqi \& De Silva 2010). In developing countries, where the penetration of mobile growth is high, they could significantly increase the use of E-Government (Abdulmohsen Abanumy and Pam Mayhew (2005). Over the last decade, developed countries have moved towards MGovernment adoption whereas developing countries are showing interest in the implementation of applications (Abdelghaffar and Magdy, 2012). Karadimas et al. (2008) classified M-Government services into two types namely push-services where citizens can get alerts and reminders and interactive service which allows two-way communication between citizens and government. There are two major categories of mobile devices namely and feature phones and smartphones. The government can use the mobile channel for providing SMS text service on feature phones and mobile apps on smartphones (UN, 2014). The Short Message Service (SMS is called text messaging to enabling users to send text messages to other users using mobile networks. The SMS is an essential service for providing government services using SMS because in some areas reaching to the citizens using only mobile channel. In the developing countries, seven out of ten have access to SMS, which means citizens, are more accessible to the SMS. In the case of land-based communication is not working, in such case, SMS based services used for accessing information on the government (Susanto and Goodwin, 2010; ITU, 2010, Aloudat and Michael, 2011). The government services based on SMS classified into six levels namely 1) Listen level: at this level, people can send their SMS in one direction only, such suggestions \& complaints 2) Notification level: It is a one- 
way communication, at this level the government sends messages to their citizens like instructions or services.3) Pullbased Information level: This is a two-way communication, between the government and citizens, such as people may ask the status of their applications and forms.4) Communication level: This level is between the citizen and the government. It is a two-way communication. 5) Transaction level: At transition level, the people can pay various taxes \& utility bills. 6) Integration level: This level integrates all servicesbased messages in a single portal, so citizens can use the services by sending SMS to one number only (Susanto et al., 2008). Implementation of services based on mobile applications for the year 2012 to the year 2014 (UN, 2014) is given in Fig 1.

\section{Fig 1: Countries offering SMS text and mobile web/app services, UN (2014)}

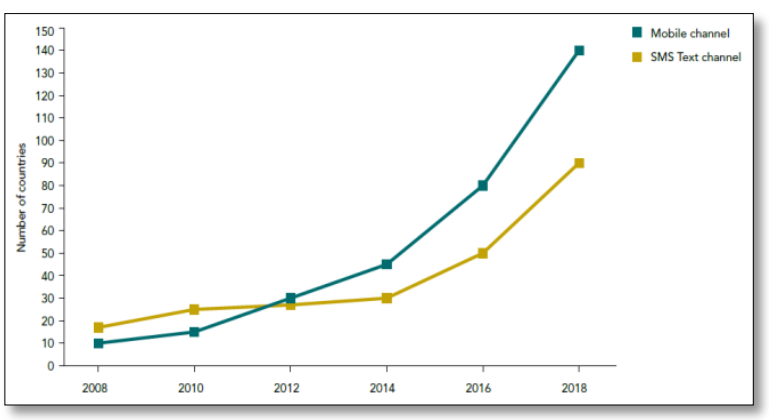

About thirty countries are providing government services through SMS and forty-nine countries are providing services through mobile apps (UN, 2014). The services mentioned in Section 2.1.1 for E-Government are further extended to the mobile based services, namely M-Government to Government (mG2G), M-Government to Employee (mG2E), MGovernment to Citizen (mG2C), M-Government to business (mG2B) (ITU, 2010; Oui-Suk, 2010).

\subsubsection{M-Government to Employees ( $m G 2 E$ )}

The mobile technology can be used by the government to track and check the employee services by using locationbased services to provide instant guidance particularly in a mission-critical application such as disaster management. As most of the government employees are using mobile devices, the government can use this opportunity and offer mobile services to them so that no need to buy devices by the government and save cost tremendously (Hellstrom 2008; BYOD, 2012; FCW, 2012). The government can offer mobile-based services to the most disadvantaged groups of the society (Aker et al., 2010). The mobile technology and human resource management may improve G2E services such as location-based services, productivity, real-time access and employee satisfaction (Hawking et al., 2004; FCW, 2012). Mobile based Government to Employee (G2E) applications used for employee travel, leave, location-based services, reminders, accessing personal records, organizational policies, emergency notifications, announcements, etc. (Hans, 2015). Providing services through the mobile applications and portals by the government is more as compared to the SMS services. The government should introduce services based on mobile technology in addition to the traditional services to the employees (Shin-Yuan Hung et al., 2013). However, only a few governments across the world are offering mobile-based solutions to their employees to get information at anytime and anywhere on demand (E-Government Unit, 2004). This gives the motivation to study this paper in the G2E services area and therefore, G2E services may be seen as a separate entity and need to be studied using mobile technology. The study of the literature reveals that the research on G2E is not yet widely analyzed in the M-Government area and therefore the adoption of Mobile based G2E may improve not only the quality of internal services but also services to the citizens. Mobile technology usage is increasing rapidly in India. Therefore, it is necessary to provide M-Government applications attention to alert employees about the benefit of G2E services. This gives motivation to this paper. The objective of this study is to investigate the deployment of MGovernment applications related to G2E services as a case of India. Therefore, the purpose of this paper is to identify possible Mobile based Government to Employee (MG2E) services discussed in detail in Section 3.

\section{MOBILE BASED G2E SERVICES}

This section proposed a classification of Mobile based G2E services (MG2E) with examples and their usage.

\subsection{Classification of Mobile based G2E services}

The Mobile-based G2E services (MG2E) are classified into two categories: 1) Informational \& Interactive services and 2) Transactional services;1) Informational and Interactive services: An informational service involves providing service information to the employees. The communication with these services becomes one-to-one and not one-to-many. Through interactive mobile based G2E services employees can connect with governments at any time and any place to send inquiries, grievances, comments, location-based services, reporting from remote areas, requests services to the concerned departments, etc. The employees may avail government services through mobile based forms and services at anytime and anywhere according to their interests. The employee receives SMS text notifications such as service, salary; leave, etc., crime reports, location-based maps \& services. Mobile applications such as real-time survey reports, employee feedback, and information sharing..2) Transaction services: Under these services, employees can make transactions such as paying taxes, filing tax returns etc. at anywhere and anytime basis. These services have more advantages as compared to the traditional services. Some Mobile based G2E services with examples and their usage with reference to the informational \& interactive services and transactional services are given in Table 2.

\subsection{Benefits with MG2E services}

\subsubsection{Government}

The mobile based G2E services offer significant opportunities to the government for efficient employee service delivery and achieving cost optimization. As mobile phones used for locating employee's exact physical location, the government to contact with their employees wherever they are. It is particularly useful to get information from the survey or field employees. The mobile device used as a data-capturing device by field employees for reporting activity levels and may seek expert advice directly from the field. Some examples are: a) Electricity employees can send the exact locations of burned or not working transformers, broken street lamp on a real-time basis through their GPS-enabled mobiles b) Health workers can update patient medical records from the field, it ensures that updated patient database is available, with the government, to save lives in time c) The government can offer various value-added services such as salaries, medical reimbursement, etc., through secured mobile payment 
gateway to their employees d) The government departments can use their employees' mobile handsets in the circumstances such as election monitoring, disaster recovery, crime reporting, drinking water, student examinations, complaint reporting, etc., to know the current status and guide them instantly.

\subsubsection{Employees}

The Mobile-based G2E services can allow employees in their daily lives. The employees can get services such as payroll, leave, transfer/postings, attendance, training, etc. through their mobile devices without going to their respective department or its website. They can get the desired services on their handsets via SMS at anytime and anywhere. The employee can also update certain services such as personal information, project status, and assets information from their mobile devices on a real-time basis. The employees can also make their attendance from the field through the GPS- enabled mobile handsets. The employees may use their handsets for information sharing with their co-workers, for an example, nurses can connect to government databases from the remote location. It will cut the need for round trips to the office and spend more time with patients. This can help, particularly in remote areas. Some examples are: Employee may get answers to their questions such as a) Number of leaves assigned and used. b) Is salary or medical reimbursement credited to my account? c) How much General Provident Fund (GPF) available? What are my projects or training details? d) In which department I have posted or transferred? e) Is my Annual Confidence Reports (ACR) received from the concerned department?

\subsubsection{Some International examples of mobile based G2E services}

Some countries are using mobile handsets to manage their resources more efficiently; some examples are given in Table 3.

Table 3: Some International examples of Mobile based government to employee services

\begin{tabular}{|l|l|}
\hline \multicolumn{1}{|c|}{ Country } & \multicolumn{1}{|c|}{ Usage } \\
\hline Afghanistan & $\begin{array}{l}\text { GPS enabled smart phones to monitor } \\
\text { the progress of the maintenance work } \\
\text { of highway roads (IC4D, 2012) }\end{array}$ \\
\hline Amsterdam & $\begin{array}{l}\text { Employees can work from anywhere } \\
\text { using phones and other personal or } \\
\text { government-issued devices } \\
\text { (Cisco,2012) }\end{array}$ \\
\hline Hong Kong & $\begin{array}{l}\text { Mobile Field Inspections of the } \\
\text { Environment Protection Department of } \\
\text { Hong Kong can send their reports } \\
\text { through mobile phones to the office. } \\
\text { Near about ten percent increase in } \\
\text { productivity and elimination of } \\
\text { duplication work (Hans, 2015). }\end{array}$ \\
\hline Liberia & $\begin{array}{l}\text { Status of water points, assessment and } \\
\text { allocation of more effective resources } \\
\text { by the Liberia's water resource } \\
\text { management plan. } \\
\text { (Source: } \\
\text { http://www.wsp.org/wsp/sites/wsp.org/ } \\
\text { files/publications/WSPFLOW-Liberia- }\end{array}$ \\
\hline
\end{tabular}

\begin{tabular}{|l|l|}
\hline & QandA.pdf). \\
\hline New Zealand & $\begin{array}{l}\text { A GPS based mobile system to check } \\
\text { its resources and employees. Using } \\
\text { these devices saves time on highway } \\
\text { maintenance work in the Auckland city } \\
\text { (IC4D, 2012). }\end{array}$ \\
\hline United Kingdom & $\begin{array}{l}\text { The North London Strategic Alliance } \\
\text { (NLSA) Street Wardens Pilot Project. } \\
\text { The aim of the project is to streamline } \\
\text { the street wardens operations using } \\
\text { mobile devices (Hans, 2015). }\end{array}$ \\
\hline United States of & $\begin{array}{l}\text { The City of Corpus Christi, United } \\
\text { States, has a comprehensive based } \\
\text { mobile application for its work and } \\
\text { asset management system (OECD; } \\
\text { ITU, 2011). The government allows } \\
\text { employees to use access their owned } \\
\text { mobile devices in their organizations. } \\
\text { (Source: } \\
\text { http://www.whitehouse.gov/digitalgov/ } \\
\text { bring-your-own-device\#_ftnref1). }\end{array}$ \\
\hline
\end{tabular}

\section{A CASE STUDY: MOBILE BASED G2E SERVICES}

\subsection{Mobile Government in India}

The National e-Governance Plan (NeGP) of the Government of India vision is "Make all Government services accessible to the citizens in his locality, through common service delivery outlets, and make sure efficiency, transparency, and reliability of such services at affordable costs to realize the basic needs of the citizens". As mobile phone subscribers are increasing in India, the citizens may get access to public services through mobile devices (mgov, 2014). The goal of mobile government services in India is "To use the massive reach of mobile phones and harness the potential of mobile applications to enable easy and round-the-clock access to public services, especially in the rural areas" (deity, 2012). Mobile Seva (services) is an initiative to start the mobile governance in the country for delivery of citizen services through mobile devices.The status of mobile services is a) Push SMS Integration: 16111399206 SMSes are pushed b) Pull SMS Integration: 1,88,59,204 SMSes are pulled c) Mobile Applications: About 1045 Live mobile applications d) IVRS Integration: About 6569854 transactions using IVRS Services e). USSD Integration: About 1449556 transactions using USSD Services, as on June 7th, 2017(source: https://mgov.gov.in/).In India, the mobile phones classified according to the computing power and prices a) Basic phone that makes phone calls and or messages (Indian rupees Rs.1, 000), b) Feature phones that can have limited access to the Internet through the app or low bandwidth $2 \mathrm{G}$ or GPRS connectivity, but have low computing power Indian Rupees in between Rs. 750 to 1500 ) and c) Smartphones (3G/4G) with Android operating system cost is Rs. 2,500 to 90,000 (HTApril, 2015).

The Smartphones and Internet connectivity are playing a vital role in keeping students away from parents, for an instance, students from villages near Tumakuru $70 \mathrm{~km}$ from Bangalore 
prefer in Tumakuru on weekends instead of going to their home simply because their villages have poor or no connectivity (Source: Times of India, daily newspaper, Delhi Edition, Dated 03.08.2015). A Survey by B2X care solutions (2014) found that $57 \%$ of Indians cannot live without their smartphones. According to the Telecom Regulatory Authority of India (TARI, 2017), as on $31^{\text {st }}$ December'2016 total telephone subscribers in India are 1151.79 million, out of which wireless subscribers are 1127.38 million and wireline subscribers are 24.41 million for urban and rural subscribers (see Table $4 \&$ Figure 2). The observation from the Table 4 is that numbers of wireless subscribers are more as compared to the wired line subscribers. Therefore, In India, the government utilizes the penetration of mobile technology in order to provide services through mobile devices.

Table 4: Telecom Subscribers up to $31^{\text {st }}$ December 2016 (TARI, 2017)

\begin{tabular}{|l|r|r|r|}
\hline Subscribers & Wireless & Wire line & \multicolumn{1}{c|}{ Total } \\
\hline Urban & 662.60 & 20.55 & 683.15 \\
\hline Rural & 464.78 & 3.86 & 468.64 \\
\hline Total & 1127.38 & 24.41 & 1151.79 \\
\hline
\end{tabular}

Fig 2: Telecom Subscription Data of Urban and Rural in India as on 31st December 2016 (TARI, 2017)

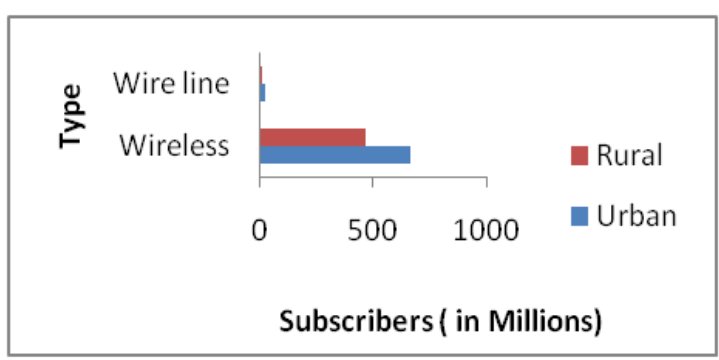

\subsection{Some Examples}

In India, Mobile based G2E services are at a very primary stage. Some initiatives are: 1) Employees E-mail policy: The government employees have an SMS facility through their official Email account (Indian Express, 2013) for instant information from the employees.2) Vacancy and Recruitment Notifications: Government of India maintained employment news offer SMS-based job vacancies, particularly from various ministries and autonomous organizations. The user has to register to get alerts on SMS-based job vacancies (ET, 2013). 3) The Defense Research Development (DRDO, Ministry of Defense, has initiated the mobile based registration of applications for recruitment. The candidate has to register for recruitment on mobile no 56677 (ET, 2013). 4) Health Information: The mobile based Central Government Health Services provided to their employees. About 3.2 million employees have used CGHS services across India (CGHS, 2013). 5) Public Safety: The Delhi Police using PCR vans with a mobile phone it will help PCR people to contact with the victims instantly for medical assistance immediately (HT, 2013). 6) Reservoir level Notifications: Using SMS based services the field engineers collected the level of reservoirs information and sent to the main office. This information is useful to check the water level during a flood to save lives and other crises. (Source: http://www.nisg.org/knowledgecenter_docs/B02040002.pdf). 7) Salary Notifications: Using SMS based services the banks are informing to the government employees about their transactions as soon as the credited/debited into their accounts.

\subsection{Research Methodology}

\subsubsection{Research Questions}

A questionnaire (see Table 5) developed after detailed discussions with employees of various State and Central government departments and explained about the proposed Mobile based G2E services as mentioned in Table 2 in order to understand and fill information in a useful manner before completing the questionnaire by the employees.

Table 5: Research Questions

\begin{tabular}{|c|l|}
\hline Sr. No & \multicolumn{1}{|c|}{ Question } \\
\hline 1 & Name of the employee: \\
\hline 2 & $:$ \\
\hline 3 & Type of Government: 1)State 2 ) Central: \\
\hline 4 & Department : \\
\hline $\begin{array}{c}\text { Are you receiving or sending the following services through } \\
\text { SMS text or mobile applications? }\end{array}$ \\
\hline 5.1 & Employee personal information (Yes/No)? \\
\hline 5.2 & Employee service information (Yes/No)? \\
\hline 5.3 & Annual confidential reports information (Yes/No)? \\
\hline 5.4 & Leave information (Yes/No)? \\
\hline 5.5 & Mobile based attendance (Yes/No)? \\
\hline 5.6 & Asset information management (Yes/No)? \\
\hline 5.7 & Grievance management system (Yes/No)? \\
\hline 5.8 & Training information (Yes/No)? \\
\hline 5.9 & Emergency information (Yes/No)? \\
\hline 5.10 & Project information (Yes/No)? \\
\hline 5.11 & Survey information (Yes/No)? \\
\hline 5.12 & $\begin{array}{l}\text { Accounts related information such as salary or } \\
\text { provident fund (Yes/No)? }\end{array}$ \\
\hline 6 & $\begin{array}{l}\text { Type of Mobile used: 1) Basic Mobile or 2) Smart } \\
\text { Phone (GPS enabled)? }\end{array}$ \\
\hline 7 & $\begin{array}{l}\text { Mobile bill payment by: 1) Government or 2) } \\
\text { Employee? }\end{array}$ \\
\hline 8 & $\begin{array}{l}\text { Owner of the Mobile: 1) Government or 2) } \\
\text { Employee }\end{array}$ \\
\hline
\end{tabular}

\subsubsection{Methodology}

The main objective of this paper is to identify M-Government implementation in India, particularly the services related to the Government to Employees (G2E). In order to examine the implementation of some Mobile based G2E services (MG2E), as mentioned in Table 2, fifteen research questions were established and provided in Table 5.The study was conducted in four States namely Andhra Pradesh, Delhi, Haryana and Kerala and some Central government departments and its autonomous organizations from January-2015 to December2015. It may be noted that employee age, gender, education, salary, and designation are not considered for this study, the only condition is the employee should currently work in any government department or its autonomous organizations. Further, in this study considered only one designation from 
one department to avoid duplication and to know the trend in implementation of MG2E services. The State and Central government wise number of employees and their working departments are summarized in Table 6.The questionnaire was sent to 200 employees out of which only 150 employees were responses to the questionnaire. Out of 150 employees, only 100 employees from 79 independent departments were shown interest and provided correct information. The responses were collected through multi-channel such as Google online forms, email, phone (wired /wireless), face-t-face discussions, social media such as Whatsapp and Facebook and traveled to the States of Andhra Pradesh and Delhi in order to investigate physically about the implementation of MG2E services. The distribution of responses is depicted in Figure 3 to Figure 7.

Table 6: State and Centre wise responded number of employees and their departments

\begin{tabular}{|l|c|c|}
\hline \multicolumn{1}{|c|}{ Government } & $\begin{array}{c}\text { No. of } \\
\text { Employees }\end{array}$ & $\begin{array}{c}\text { Number of } \\
\text { Departments }\end{array}$ \\
\hline a) State \\
\hline Andhra Pradesh & 22 & 13 \\
\hline Delhi & 22 & 21 \\
\hline Haryana & 11 & 06 \\
\hline Kerala & 13 & 10 \\
\hline b ) Central & 32 & 23 \\
\hline Total & $\mathbf{1 0 0}$ & $\mathbf{7 3}$ \\
\hline
\end{tabular}

Fig 3: Number of Employees used G2E services using Mobile app or SMS

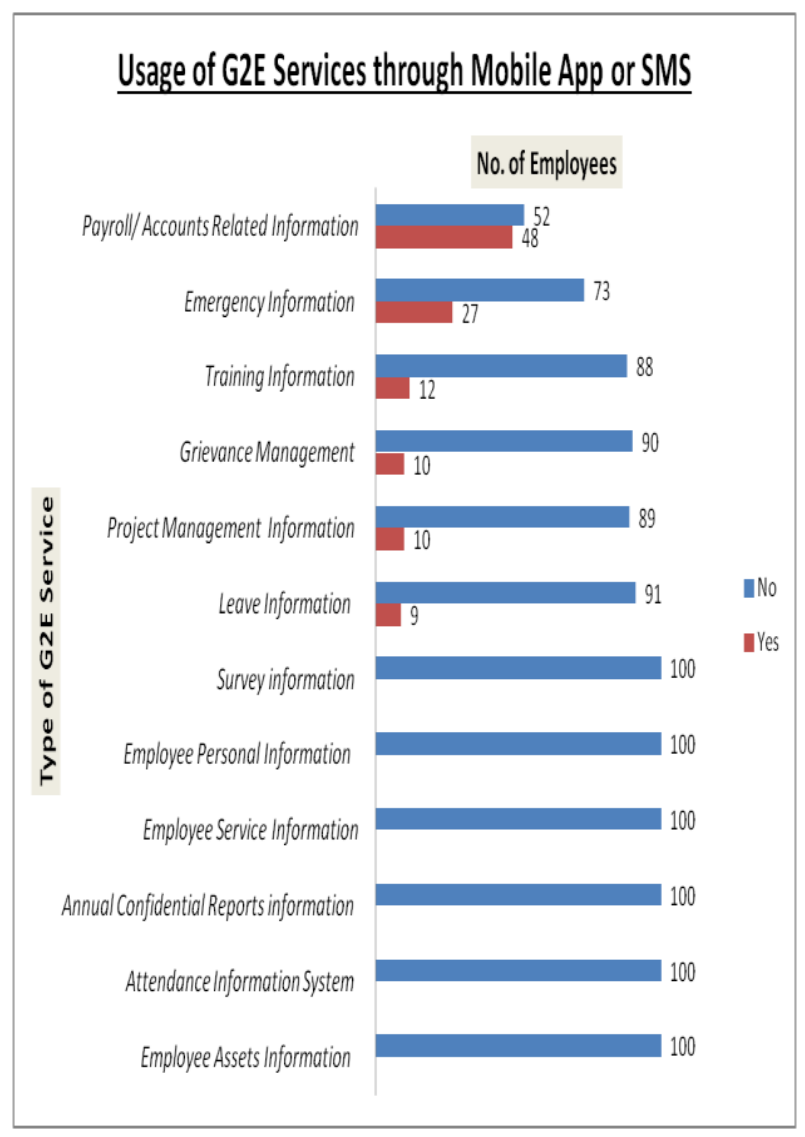

Fig 4: Percentage (\%) of G2E services provided through Mobile App or SMS

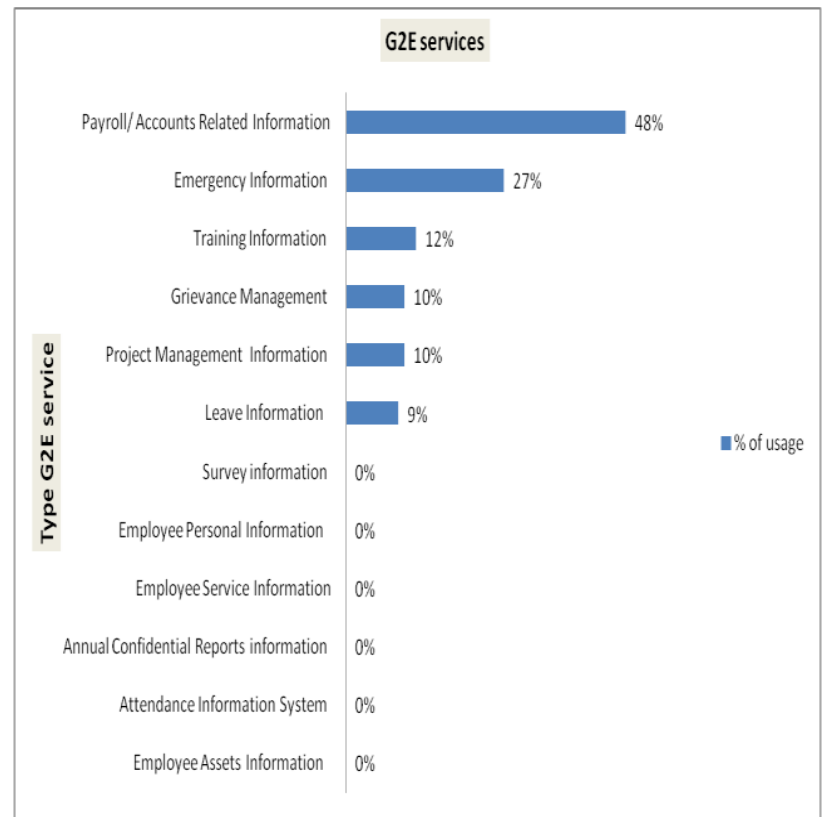

Fig 5: Distribution of type of mobile device

\section{Type of Mobile Used}

- Basic (2G) - Smart Phone $(3 G / 4 G)$

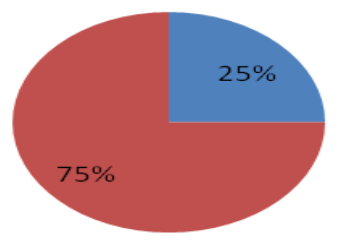

Fig 6: Distribution of payment of mobile bill

\section{Mobile Bill Payment By}

Employee Government

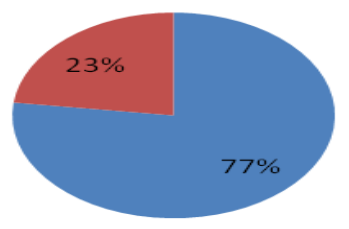

Fig 7: Distribution of Mobile Owner

\section{Owner of the Mobile}

Employee Government

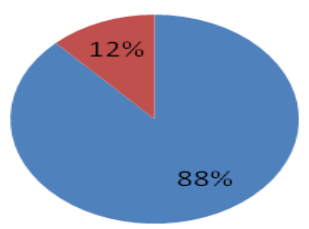




\subsubsection{Results and Findings}

This paper examines the implementation of Government to Employee (G2E) services using mobile technology in the Indian context. The study results presented in Figures 3 to 7.The results indicate that mobile based G2E services are not yet implemented in Central or State government departments even though growth of mobile is increasing including in rural areas in India. The findings (see Figures 3 to Figure 7) indicate that only six out of twelve services, namely Payroll notification (48\%), Emergency services (27\%), Training (12\%), Grievance management (10\%), Project Management (10\%), and Leave information (9\%) used as Simple Mailing Services (SMS) notifications and the remaining six services were not yet initiated. It may note that the payroll notifications received from the bank, but not from the government departments. Other services, namely Survey information, Employee Personal Information, Employee Service Information, Annual Confidential Reports information, Attendance Information System and Employee Assets Information are not yet initiated in the study area of government departments. It was observed that generally three types of phones were used by the employees a) Basic phones (phone calls and messages) b) Features phones (limited access to the Internet through apps or low bandwidth $2 \mathrm{G}$, but limited computing power) and c) Smartphones (Own operating system such as Android usually with 3G/4G).

Some employees are having both basic phones and smartphones, but they will use a basic phone in traveling due to fear of theft or misplacing the mobile device and they use smartphones in their house. The change of generation is significant from $2 \mathrm{G}$ to $3 \mathrm{G}$ and $3 \mathrm{G}$ to $4 \mathrm{G}$ as smartphones are getting cheaper and cheaper phone is getting smarter. For an example, this study started in the month of January 2015 during that period some employees was informed that they are using $2 \mathrm{G}$ mobile, but later on, a majority of employees were shifted from $2 \mathrm{G}$ to $3 \mathrm{G} / 4 \mathrm{G}$ generation. About $75 \%$ employees informed that they are using smartphone $3 \mathrm{G} / 4 \mathrm{G}$ with GPS enabled services. The study also examined owner of the device and mobile payment. Generally, government departments are not providing mobiles or payment of mobile to all employees. It is based on the functional requirement of the employees. Some government departments are providing mobile devices and paying bills, it depends on the functional requirement of employees' for an example in Andhra Pradesh, the government is providing mobile devices and paying mobile bills partially for cretin employees such as section officer and above. The Delhi government is also paying mobile bills partially to their employees such as health workers. Whereas in Central government partial mobile payment made to the employees from deputy secretary level onwards or functional requirement of the employees. About $88 \%$ of employees informed that mobile is their personal and charges paid by themselves, $12 \%$ of employees having the government provide mobiles and partially paid by the government. The mobile bill payment results show that the government paid partially that is only $23 \%$ and employees paid by them is $77 \%$.

If the device is owned by the employee (Bring Your Own Device (BYOD) then he/she may switch off, if they do not want in such case services of an employee may not available during emergency cases such as natural disaster. The government is providing the device (basic features) to the employees so that their services can be used on a $24 \times 7$ basis. At the same time, providing devices to all employees to the government is a financial issue. Therefore, the government should pay mobile bills to the employees according to their functional requirements. The only significance perception is that most of the banks and some government departments were sending SMS alerts information related on the payroll, health, electricity, and water. It was observed that employee shares government information such as circulars, notices, and emergency information among themselves using social networks such as WhatsApp and Facebook. These results may be generalized to other employees also because, in the general, Code of Conduct Rules (CCS) and regulations are common to all employees with respective to the Central/State government departments. It is concluded the results of the study indicate that the majority of the Mobile based G2E services are not yet implemented in various State and Central government departments. Therefore, the government should initiate to develop mobile based G2E services as mentioned in Table 2, for effective G2E services which are useful not only for internal efficiency, but for the effective citizen services, for instance, filed employee can mark their attendance from their GPS-enabled mobile and it can track by the department.

This study has some limitations and issues, as this paper investigated MG2E services based on information collected from only 150 employees from 79 independent departments of State and Central government. There are a number of issues while collecting information from the employees such as a) Employees are not responding timely b) Not providing accurate information or they do $\mathrm{t}$ want to participate in this survey due to scare. c) Information collected from multichannel may be incompatible, because the employee may not provide the same information on each channel, this need to be verified carefully to avoid duplication of information. Therefore the government or researchers should take care of the paper limitations while implementing the MG2E services.

\section{MOBILE BASED SERVICES - ISSUES AND CHALLENGES}

The development of applications based on mobile technology in the government is still in an early stage (Abramowicz et al., 2006). The best mobile based government services are not yet implemented. The impact on government mobile services as compared with E-Government services is still unknown (infoDev 2009; Hanna 2010). The government departments are not able to contact with their employees and citizens, particularly in remote areas (E-Government, 2010), due to various reasons. Some government departments across the world are not interested in providing citizen services through mobile based applications (OECD and ITU 2011). Many departments of the government are not in a position to implement applications runs on mobile devices by themselves (WB, 2012). The countries having lower- middle and low income are provided below five present mobile based services, whereas it increases ten percent in the case of upper middle-income countries (UN, 2012), that means for providing mobile based services by the government departments should have necessary budget requirements. There are numerous challenges such as various mobile technologies to identifying the services, security of the financial transaction, service unavailability, network congestion, delay in SMS delivery, personalization of services, the language of the user, interface design, screen size, call drops and capabilities of the devices (Misuraca, 2009). Near about fifty-seven percent of the population of the world is not using the Internet, because of cost effective for at the last mile connectivity (Source: http://egov.eletsonline.com/2015/04/mobile-broadbandlandscape-in-india/). Therefore, before implementing MG2E 
services, the government should discuss with their concerned stakeholders.

\subsection{Issues and Challenges}

This section discusses some issues and challenges associated with the implementation of mobile based G2E services as mentioned in Table 2. Some issues and challenges are a) Lack of Employee Unique-ID: Most of the government departments are managing and maintain employees-ID at a department level. As a result as and when employees moved from one department to another department new employee-id will be issued. These issues are a lack of unique employee-ID. b) Lack of Electronic based Attendance Systems: Majority of government departments are using a manual attendance (sign in the book). Some government departments are using multiple employee attendance systems such as physically sign on book, bio-metric, thumb, finger, iris, and card based etc., for their employees. Interoperability among these multiple attendance systems may be issued to the government in the implementation of a mobile based attendance system c) Lack of Electronic Service Book: The employee's service book, which containing the complete history of an employee (such as nativity, family information, joining to retirement details including salary and leave record), which is maintained as a hard copy with many government departments in India. An electronic version of service books of all employees has to be generated and updated timely in order to provide mobilebased services to employees on demand at anytime and anywhere basis. However, computerization of service books of all employees in a large scale basis is a very challenging to the Central/State government departments d) Lack of Unique Employee Information Systems: Lack of uniformity in employee information systems across government departments is another issue for developing mobile based G2E services. Employee information such as Financial and accounting system, Court cases, Assets, Annual confidence reports (ACR), training, grievances, etc. managing and maintaining the departments independently through manual maintenance and/or using different software f) Employee Information available in Multiple Languages: Many government departments are managing and maintaining employee records such as a service book in their respective languages such as Hindi, Tamil, Telugu etc. However, when an employee moves from one State to State or Central government department then it is very difficult to read and understand the content of the service book. Maintaining the employee service book in multiple languages is another challenging issue to the government. However, the information should be available to the employees in their local language is a need for employee satisfaction. Interoperability among various Indian languages is needed to be taken care while developing mobile based G2E services across the country.

\section{RECOMMENDATIONS}

According to the Telecom Regulatory Authority of India (TARI, 2017), wireless subscribers are increasing as compared to the wired subscribers both in urban and rural areas, which means citizens are preferring wireless especially mobile devices. The government should take this opportunity and provide mobile based services to the employees in an efficient way. However, the case study of this paper shows that even through employees are having mobile devices most of the State and Central government departments are not yet implemented government to employee's services through mobile technology. Since every employee is having a mobile device, the government may initiate important services of
MG2E as mentioned in Table 2.The issues and challenges with MG2E as mentioned in Section 5.1 should note before implementation of MG2E services, and make sure that all information related the employees should be in digital form. The government should take feedback from their employees and track the usage of mobile-based services in order to improve those services. If some MG2E services are not frequently used by the employees, such services should analyze and accordingly modify those services. The services should support multiple Indian languages for employee satisfaction particularly at local or village level. The budget is the most important to provide MG2E services; therefore, the government may initiate few services of MG2E as mentioned in Table 2, instead of providing all services at one time. The employee's acceptance of services based on mobile technology depends on the ease of use, usefulness, and availability. In order to upgrade their skills, necessary training may be provided to the employees from time to time.

\section{CONCLUSIONS}

The mobile technology is an alternative channel to the government departments to provide services to the citizens. Many governments across the world are providing services to their stakeholders using mobile technology in order to improve their services. The objective of this study is to study the adoption of M-Government services, particularly services related to the employees in the Indian government departments.

This study finds that majority of MG2E services are not yet implemented in many government departments in India, even though some services are provided through SMS notifications. This survey indicates that a majority of employees are having their own smartphones and mobile charges paid by them. Therefore, the government departments should start MG2E based services at least on a pilot basis, for empowering employees and to minimize investment on mobile devices and mobile bill payments. However, innovation, availability, cooperation from the government and employees are important factors to initiate MG2E based services.

\section{REFERENCES}

[1] Abdelghaffar, H. and Magdy, Y. (2012). The adoption of mobile government services in developing countries: the case of Egypt', International Journal of Information and Communication Technology Research, Vol. 2, No. 4, pp.333-341.

[2] Abramowicz, W., Bassara, A., Filipowska, A., and Zebrowski, P.,(2006). Mobility implications for $\mathrm{m}$ government platform deign. Cybernetics and system: an international journal, 37:119-135, Taylor\&Francis Group, DOI: 10.1080/01969720500428255.

[3] Afghanistan (2012). Using GPS-enabled smartphones, have been used in Afghanistan to monitor the quality and progress of road construction" , Available at http://aidc.af/aidc/.

[4] Aker, Jenny C., and Isaac M. Mbiti. 2010. Mobile Phones and Economic Development in Africa, Journal of Economic Perspectives, Volume 24, Number 3,Summer 2010, Pages 207-232.

[5] Alvydas Baležentis and Gintarè Paražinskaitè (2012). Benchmarking of the Government to Employee (G2E), Social Technologies 2012, 2 (1), p. 53-66. ISSN 20297564 (online). 
[6] Aloudat, A. \& Michael, K. (2011). "Toward the regulation of ubiquitous mobile government: a case study on location-based emergency services in Australia", Electronic Commerce Research, Vol 11, No 1, pp 31-74.

[7] Albesher, A.S. and Stone, R.T. (2016) 'Current of MGovernment research: identifying future research opportunities', Int. J. Electronic Governance, Vol. 8, No. 2, pp.119-139.

[8] Alrazooqi, M. \& De Silva, R. (2010) 'Mobile and Wireless Services and Technologies for M-Government Solution Proposal for Dubai Government', WSEAS Transactions on Information Science and Applications, Vol. 7, No. 8, pp. 1037 - 1047.

[9] Al- khamayseh, S., Lawrence, E., and Zmijewska, A. (2006). Towards understanding success factors in interactive mobile government. Proceedings of Euro mGOV 2006: The Second European Conference on Mobile Government, Brighton, UK.

[10] Aloudat, A., Michael, K., \& Abbas, R. (2009). "Location-Based Services for Emergency Management: A Multi-stakeholder Perspective", In Proceedings of the Eighth International Conference on Mobile Business (ICMB 2009) June 26-28, 2009 - Dalian University of Technology (DUT), Dalian, China.

[11] Amailef, K. \& Lu, J. (2008) 'm-Government: A Framework of Mobile-based Emergency Response Systems', in 3rd International Conference on Intelligent System and Knowledge Engineering, Vol. 1, pp. 1398 1403.

[12] Antovski, L. and M. Gusev (2005). M-Government Framework. Proceeding of Euro mGOV 2005: The First European Conference on Mobile Government, Brighton, UK.

[13] Asheeta B , Rowena W , Subramaniam J, Peter Silarszky (TTL) (2008).the role of mobile phones in sustainable rural poverty reduction, Available at $\mathrm{http} / / /$ siteresources.worldbank.org/extinformationandcom municationandtechnologieS/Resources/The_Role_of_Mo bile_Phones_in_Sustainable_Rural_Poverty_Reduction_ June_2008.pdf,, visited on 26.08.2016.

[14] Black Berry (2014). Smartphones: A Savvy Strategy for Government Employees Available at: http://in.blackberry.com/content/dam/blackBerry/pdf/whi tePaper/northAmerica/english/Smartphones_Government _Whitepaper.pdf, visited on 03.2.2015.

[15] Broadband (2015), The of Broadband http://www.broadbandcommission.org/Documents/report s/bb-annualreport2015.pdf, available at visited on 30.10 .2015

[16] B2X (2014) B2X Global Survey Reveals Device Addiction and Other Surprising Smartphone Habits around the World, available at https://www.b2x.com/en/b2x-global-survey-revealsdevice-addiction-and-other-surprising-smartphonehabits-around-world, visited on February 20, 2015.

[17] Carter, L. \& Belanger, F. (2005). The utilization of EGovernment services: Citizen Trust, innovation and acceptance factor. Information Systems Journal, 15 (1), $5-25$.

[18] Choudrie, J., and Dwivedi, Y. (2005). A Survey of Citizens Adoption and Awareness of E-Government
Initiatives, the 'Government Gateway': A United Kingdom Perspective. E-Government Workshop Brunel University, London.

[19] Cisco Visual Networking Index (2012): Global Mobile Data Traffic Forecast Update, 2012-2017 Available at: http://www.cisco.com/en/US/solutions/collateral/ns341/n s525/ns537/ns, visited on 12.05.2014705/ns827/white_paper_c11-520862.htm, visited on 12.3.2014.

[20] Cisco (2012) . Mobile Collaboration in the Public Sector, Available at https://www.cisco.com/web/strategy/docs/gov/next_gen_ mobile_collab_whitepaper.pdf, visited , 02.01.201.5

[21] CGHS (2013) beneficiaries spread across India. Available at :http://www.gconnect.in/news/india-is-thesecond-largest-mobile-phone-user-in-world.html, visited on 13.04.2013.

[22] DEITY, (2012): Framework of Mobile Governance, available http://deity.gov.in/sites/upload_files/dit/files/Framework Mobile_Governance_1712012.pdf, visited on 02.02 .2015

[23] ET (2013): Employment News, New Delhi 4-10 May 2013

[24] E-Government Unit (2004): Services Commission. Achieving E-Government 2004: a Report on Progress towards the New Zealand E-Government Strategy. E-Government Unit Research Paper. Wellington: SSC, October 2004, Available at http://www.ssc.govt.nz/node/6405, Visited on 06.04 .2013

[25] El Kiki et al., 2005; Ntaliani et al., 2007: M-Government is considered as a subset of E-Government comprising another channel to provide governmental information and services

[26] El Kiki, T., Lawrence, E., \& Steele, R. (2005) "A Management Framework for Mobile Government Services". CollECTeR, Sydney, Australia. [Online], http://www.mgovernment.org/resurces/mgovlab_afgik.p df, visited on 20.12.2013.

[27] El-kiki, T., Lawrence, E \& Steele, R. 2005. A Management Framework for Mobile Government Services. CollECTeR. Sydney, Australia.

[28] E-estimated (2015), Hindustan times daily news paper, new delhi edition ,13.10.2015.

[29] E. Valcourt, J. Robert, \& F. Beaulieu, (2005). Investigating mobile payment: supporting technologies, methods, and use. IEEE International Conference on Wireless And Mobile Computing, Networking And Communications, (WiMob'2005), Aug. 2005 Page (s): 29 - 36 Vol. 4 Digital Object Identifier 10.1109/WIMOB.2005.1512946.

[30] European Commission (2004). Multichannel Delivery of eGovernment Services, Available at http://ec.europa.eu/idabc/servlets/Doc282e.pdf?id=16867 , visited on 03.05.2013.

[31] FCW (2012): Employees can't do their jobs effectively without their mobile devices, Available at http://fcw.com/microsites/2012/download-mobile-andwireless/01-employee-mobile-device-needs.aspx， visited on 13.12.2013. 
[32] Golubeva A., Merkuryeva I (2006). Demand for online government services: Case studies from St. Petersburg. Information Polity 11. P. 241-254.

[33] Ghyasi, A. Farshid and Kushchu Ibrahim (2004) " mGovernment: Cases of Developing Countries", to appear at European Conference on E-Government (ECEG 2004), Trinity College, Dublin.

[34] Hawking et al. (2004): Hawking P., Stein A., Foster S. 2004. e-HR and Employee Self Service: A Case Study of a Victorian Public Sector Organization. Issues in Informing Science and Information Technology, proceedings. P.1017-1026.

[35] Hans J Schno (2015). E-Government: Information, Technology, and Transformation, published by Routledge.

[36] Hassan,M., Jaber,T. Hamdan, Z. (2009). Adaptive Mobile- Government Framework. Proceedings of International Conference on Administrative Development: Towards Excellence in Public Sector Performance, Riyadh, Saudi Arabia.

[37] HTApril (2015). Smart Feature phones ,New gizmoz aid dizzy Net boom, Hindustan Times ,Daily News paper New Delhi, edition Saturday, April 04. 2015.

[38] Heeks, R. (2013) Understanding E-Government, EGovernment course unit handout, IDPM, University of Manchester, Manchester, 27 September.

[39] Hellstrom (2008). Hellstrom, J. 2008. "Mobile Phones for Good Governance: Challenges and Way Forward." Draft discussion paper. http://mobileactive.org/research/ mobile-phones-good-governance challenges and-wayforward.

[40] Ho et al., (2005): Ho, K. K. W., Yu, C.C. and Lai, M. C. L. (2005). An Exploratory Study on the User Adoption of G2C and G2E E-Government Projects. In: Proceedings of the 6th International We-B (Working for E-Business) Conference, Melbourne, Australia.

[41] HT (2013): PCR van staff in Delhi to be equipped with mobile phones, New Delhi, July 15, 2013, Available at: http://www.hindustantimes.com/StoryPage/Print/109307 5.aspx, visited on 15.7.2013.

[42] ITU (2010): Electronic Government for Developing Countries, Available from http://www. itu.int/ITU$\mathrm{D} /$ cyb/app/docs/e-gov for dev countries-report.pdf, Accessed on 28.09.2012.

[43] IC4D (2012): Information and Communications for Development, Maximizing Mobile, available at http://siteresources.worldbank.org/extinformationandcom municationandtechnologies/Resources/IC4D-2012Report.pdf, visited on 13-03-2015.

[44] Internet and Mobile Association of India (IAMAI, 2015). Available http://iamai.in/media/details/3658\#sthash.zI5vY9Vf.T2Z Lqv1n.dpuf, visited on 17.12.2015

[45] Igovernmnet (2013) .India 3rd largest Internet user after US, China, available at http://www.igovernment.in/igov/news/36724/india-3rdlargest-internet-user-china, visited on 27.08.2013.

[46] Indianexpress, (2013): Employees e-mail policy, available at http://indianexpress.com/article/india/indiaothers/centre-has-2-weeks-for-employees-email-policy
[47] infoDev. 2009. "eGovernment Primer: Using ICT for Public "Sector Reform." Attp://www.infodev.org/en/Project.39.html.

[48] Ishmatova, D. and Obi, T. (2009) 'M-Government services: user needs and value', Journal of EGovernment Policy and Regulation, Vol. 32, No. 1, pp.39-46.

[49] Kalakota, Ravi, \& Marcia Robinson (2001), E-Business 2.0: Roadmap for Success, Addison Wesley.

[50] Kim, Y., Yoon, J., Park, S. \& Han, J. (2004) 'Architecture for Implementing the Mobile Government Services in Korea', in Conceptual Modelling for Advanced Application Domains, Springer, Heidelberg, Berlin, pp. $601-612$.

[51] Karadimas, N.V., Papatzelou, K. \& Papantoniou, A.N. (2008) 'M-Government Services in Greece' in Proceedings of 22nd European Conference on Modeling and Simulation, Vol. 135, pp. 71-74.

[52] Kuscu, M. H., Kushchu, I., \& Yu, B. (2008) Introducing Mobile Government. In A. Anttiroiko (Ed.), Electronic Government: Concepts, Methodologies, Tools, and Applications (pp. 227-235). IGI Global.

[53] Kushchu, I., \& Kuscu, H. (2003). From E-Government to M-government: Facing the Inevitable, The 3rd European conference on E-Government (ECEG03), Trinity College, Dublin, p. 253- 260.

[54] Mohd. Nishat Faisal and Faisal Talib (2016).EGovernment to m-government: a study in a developing economy, Int. J. Mobile Communications, Vol. 14, No. 6, 2016.

[55] Markellou P., Panayiotaki A., Tsakalidis A. 2007. LevelBased Development of E-Government Servines // Encyclopedia of Digital Government. Vol..1. Ed. AriVeikko Anttiroiko and Matti Mälkiä..

[56] Mahatannankoon, Wen and Lim (2006) The Government have advantages using mobile technologies as delivery channels because they have these features: continuous availability, location-centric, convenience, customization, and identifiability.

[57] MCIT (2009). Ministry of Communications and Information Technology Indicators, MCIT, Cairo, Egypt. Available at www.mcit.gov.eg/indicator.

[58] mgov (2014), Mobile Government, India Available at http://mgov.gov.in/msdp_second.jsp?ln=eng, Visited on 20.12.2014.

[59] Mofleh, S., and Wanous, M. (2008) Understanding Factors Influencing Citizens' Adoption of eGovernment Services in the Developing World:Jordan as a Case Study. Journal of Computer Science, vol. 7, No 2, pp.111.

[60] Morawczynski, O. \& Miscione, G. (2008). "Exploring Trust in Mobile Banking Transactions: The Case Of MPesa In Kenya", Social Dimensions of Information and Communication Technology Policy, pp 287-298.

[61] New Zealand: Cities are also using mobile devices to monitor the status of ongoing programs. Auckland, New Zealand, a GPS-based handheld system that allows on highway maintenance work.

[62] Omar Al-Hujran (2012). Toward the utilization of MGovernment services in developing countries: a 
qualitative investigation International Journal of Business and Social Science, Vol. 3 No. 5; March 2012.

[63] OECD (2011): Benefits and outcomes of m-government, m-government: mobile technologies for responsive governments and connected societies, available at http://www.oecd.org/gov/public-innovation/mgovernment.htm, visited on 12.03.2013.

[64] OECD (Organisation for Economic Co-operation and Development) and ITU (International Telecommunication Union). 2011. "M-Government: Mobile Technologies for Responsive Governments and Connected Societies, available at http://www.itu.int/ITUD/cyb/app/m-gov.html, visited on 23.06.2014,

[65] Oui-Suk, Uhm (2010):Introduction of m.Government \& IT Convergence Technology, KAIST Institute for IT Convergence.

[66] Owens, John \& Anna, B. (2006), "Catching the Technology Wave: Mobile Phone Banking and Text-APayment in the Philippines", available at http://www.chemonics.com/projects/content/GCash.pdf, Accessed 13 Jun 2012,

[67] Rao (2011), Collaborative Government to Employee (G2E): Issues and Challenges to E-Government, Journal of E-Governance, Volume 34, Number 4 / 2011, Pages 214-229.

[68] Roit Pandey and K.S.Vijaya Sekhar, (2012): EGovernance Techno-Behavioural Implications :From eGovernance to $\mathrm{m}$-Governance-The Way Forward, available at http://www.iceg.net/2011/images/TechnoBehavioural\%20Implications.pdf, visited on 10.05.2014.

[69] Ruel H. Bondarouk. T. Looise J. K. 2004. EHRM: Innovation or Irritation? Utrecht. P. 27-29.

[70] Satriyantono T (2001).: “Aplikasi Wireless Berbasis SMS di Era GPRS dan 3G”, MTI ITB Seminar.

[71] Shin-Yuan Hung a,, Chia-Ming Chang and, Shao-Rong Kuo (2013): User acceptance of mobile E-Government services: An empirical study:, Government Information Quarterly, Volume 30, Issue 1, January 2013, Pages 3344.

[72] Susanto, T. D. and R. Goodwin (2006) 'Opportunity and Overview of SMS-based E-Government in Developing Countries', The Internet Society II: Advances in
Education, Commerce \& Governance, the New Forest, UK, WIT Press, vol. 36, no. 10.

[73] Susanto, T. D., R. Goodwin, et al. (2008) 'A Six-Level Model of SMS-based E-Government', International Conference on E-Government 2008, Melbourne, ICEG.

[74] Susanto, T. D. and R. Goodwin (2010): Factors Influencing Citizen Adoption of SMS-Based EGovernment Services. Electronic Journal of EGovernment. Vol. 8, Issue 1, pp. 55 - 71. Available at http://www.ejeg.com/.

[75] TARI(2017). Telecom Subscription Data as on 31st December, 2016, Available at http://www.trai.gov.in/sites/default/files/Press_Release_1 1_17_Feb_2017_Eng_0.pdf,Visited on 10.03.2017.

[76] Tang H. et all. 2011. Using Association Rules Mining to Provide Personalized Information in E-Government. International Conference $\mathrm{E}$-Business and $\mathrm{E}$ Government (ICEE) in China,

[77] Townsend, A. (2002). 'Mobile and Wireless Technologies: Emerging Opportunities for Digital.Government', Proceedings of the National Conference on Digital Government Research, Los Angeles.

[78] World Bank (2012). Making Government Mobile, available at http://siteresources.worldbank.org/extinformationandcom municationandtechnologies/Resources/IC4D-2012Chapter-6.pdf, visited on 20.2.2013.

[79] UN, (2012): United Nations E-Government Survey 2012 , Available at http://unpan3.un.org/egovkb/Portals/egovkb/Documents/ un/2012-Survey/Chapter-4-Supporting-multichannelservice-delivery.pdf, visited on 20.03.2014.

[80] UN, (2014): United Nations E-Government Survey 2012, Available at https://publicadministration.un.org/egovkb/Portals/egovk b/Documents/un/2014-Survey/E-Gov_Complete_Survey2014.pdf, visited on 08.03.2016.

[81] UN, (2016): United Nations E-Government Survey 2016, Available at on http://workspace.unpan.org/sites/Internet/Documents/UN PAN96407.pdf, vested on 10.03.2017.

\section{APPENDIX}

Table 2: Mobile based G2E services, examples, and its Usages

\begin{tabular}{|c|l|l|}
\hline Type of MG2E Service & \multicolumn{1}{|c|}{ Examples } & \multicolumn{1}{|c|}{ Usage } \\
\hline \multicolumn{1}{|c|}{ a) Informational and Interactive services } & $\begin{array}{l}\text { Employee personal information such as name, age, } \\
\text { date of birth, marital status, permanent \& present } \\
\text { contact details and family information } \\
\text { Example: Updating of Contact information } \\
\text { Employee_Id: --; Present address:-- } \\
\text { Information }\end{array}$ & $\begin{array}{l}\text { The employee can update their personal } \\
\text { information through their mobile as and } \\
\text { when changes occur so that updated } \\
\text { employee personal information available to } \\
\text { the government. }\end{array}$ \\
\hline 2)Employee Service & $\begin{array}{l}\text { Service information such as a) previous \& present } \\
\text { posting, transfer, promotion and retirement b) Such }\end{array}$ & $\begin{array}{l}\text { Service information such as appointment, } \\
\text { transfer and promotion information, etc. will }\end{array}$ \\
\hline
\end{tabular}




\begin{tabular}{|c|c|c|}
\hline Information & $\begin{array}{l}\text { as superannuation, resignation, termination, } \\
\text { retirement on voluntary basis etc. C) Health \& } \\
\text { Leave information. } \\
\text { Example: Transfer Notification } \\
\text { Name: --- } \quad \text { Present Dept: --- } \\
\text { Transfer Dept: -- Place of posting: ---- } \\
\text { With effect from (w.e.f) Date:-- }\end{array}$ & $\begin{array}{l}\text { be available instantly as SMS to the } \\
\text { employees. It gives advance information to } \\
\text { the employees to know the status of their } \\
\text { appointments/transfers/Promotions. }\end{array}$ \\
\hline $\begin{array}{l}\text { 3)Annual Confidence } \\
\text { Reports (ACR) }\end{array}$ & $\begin{array}{l}\text { Annual Confidence Reports (ACR) status } \\
\text { notifications will be available to the employees. } \\
\text { Example: ACR notifications } \\
\text { Employee_Id: -----, Department:--- } \\
\text { ACR Reported year: -- ,ACR Received year: --- }\end{array}$ & $\begin{array}{l}\text { Generally, employees do not know whether } \\
\text { their ACR received by the concerned } \\
\text { department (where their service book is } \\
\text { maintained) or not... The SMS based ACR } \\
\text { notifications will help them to know the } \\
\text { status of ACR reports at anytime and } \\
\text { anywhere. }\end{array}$ \\
\hline 4)Leave Management & $\begin{array}{l}\text { Available, apply and approval of Leaves of } \\
\text { employees done through their mobile handsets. } \\
\text { Example: Leave(s) notification } \\
\text { Employee_Id: ------- } \\
\text { Department: -- } \\
\text { Causal Leaves (Assigned/used): -- } \\
\text { Earned Leaves (Assigned/used): -- } \\
\text { Medical Leaves (Assigned/used):-- }\end{array}$ & $\begin{array}{l}\text { Mobile based real time leave information is } \\
\text { particularly useful for field or survey } \\
\text { employees. The employees can check their } \\
\text { leave record as and when required on } \\
\text { demand without consulting with their } \\
\text { concerned department. }\end{array}$ \\
\hline 5) Asset Management & $\begin{array}{l}\text { It is related to the employee's movable and } \\
\text { immovable asset information. } \\
\text { Example: Assets notification } \\
\text { Employee_Id:---- ,Department:--- } \\
\text { Movable assets: ---- ,Immovable assets:------ } \\
\text { As on Date:---- } \\
\text { Intimated to tax dept. (Yes/No):--- }\end{array}$ & $\begin{array}{l}\text { Movable and immovable information } \\
\text { updated by employees through their mobiles } \\
\text { at any time and any place, so that the } \\
\text { updated assets Information will be available } \\
\text { to the government to track employees' asset } \\
\text { information for transparency. }\end{array}$ \\
\hline $\begin{array}{l}\text { 6) Attendance } \\
\text { Management }\end{array}$ & $\begin{array}{l}\text { The employee may send their attendance through } \\
\text { GPS enabled (Location based) Mobile phones. } \\
\text { Example: Attendance } \\
\text { Employee_Id::------- ,Department: -- } \\
\text { Attendance (Present/Leave/Unmarked):- } \\
\text { Date: --/--/--- }\end{array}$ & $\begin{array}{l}\text { It is very useful, particularly for field or } \\
\text { survey employees. The employees can mark } \\
\text { their attendance from a remote location. } \\
\text { Since it is based on Global Position System } \\
\text { (GPS), the exact location will be recorded. It } \\
\text { is also useful to the government to check } \\
\text { whether an employee is actually working in } \\
\text { the field or not. }\end{array}$ \\
\hline $\begin{array}{l}\text { 7)Grievance Redressal } \\
\text { system }\end{array}$ & $\begin{array}{l}\text { Employees can send, receive and check grievance } \\
\text { status through Mobile Example: Grievance Status } \\
\text { Employee_Id::------- ,Grievance_id:--- } \\
\text { Department:----,Received to date:-- } \\
\text { Status:--- }\end{array}$ & $\begin{array}{l}\text { Employees can send, receive and check their } \\
\text { grievances from anywhere and anytime } \\
\text { without going to the department. It is most } \\
\text { useful in the remote areas, where internet } \\
\text { penetration is low. }\end{array}$ \\
\hline $\begin{array}{l}\text { 8) Recruitment and } \\
\text { Selection information }\end{array}$ & $\begin{array}{l}\text { Registered users get recruitment and selection } \\
\text { related information through SMS alerts } \\
\text { Example: Employee Selection alerts } \\
\text { Application_id:---- , Job_code:---- } \\
\text { Status [Selected/ Not selected]:---- } \\
\text { Remarks:---- }\end{array}$ & $\begin{array}{l}\text { Recruitment and selection information will } \\
\text { be available to the registered users as SMS. } \\
\text { The mobile channel is useful in case of } \\
\text { information is not received through postal or } \\
\text { other modes of services. It will save time } \\
\text { and cost as users will get instant information } \\
\text { as SMS without visiting a } \\
\text { website/department or print media. }\end{array}$ \\
\hline 9) Training information & $\begin{array}{l}\text { Training information available as SMS alerts to the } \\
\text { employees. } \\
\text { Example: Training notifications } \\
\text { Employee_id: ----- Training on:--- } \\
\text { From date: ---, To date:---- ,Venue: --- }\end{array}$ & $\begin{array}{l}\text { The employee may receive training } \\
\text { information as SMS so that he/she may } \\
\text { attend training without waiting for a hard } \\
\text { copy of training information. }\end{array}$ \\
\hline
\end{tabular}




\begin{tabular}{|c|c|c|}
\hline $\begin{array}{l}\text { 10) Emergency } \\
\text { Information }\end{array}$ & $\begin{array}{l}\text { Emergency information will be available as SMS } \\
\text { notifications to the employees so that they may } \\
\text { attend the specified location to save people and/or } \\
\text { property. } \\
\text { Example: Emergency Notification } \\
\text { Employee_id:--- } \\
\text { Emergency type: --- Image:--- } \\
\text { Place: --- Date:-- }\end{array}$ & $\begin{array}{l}\text { The departments such as police, fire may } \\
\text { send emergency information as SMS to the } \\
\text { employees, so that they may attend and send } \\
\text { live reports and pictures through their } \\
\text { mobiles. The live reports are useful to the } \\
\text { higher authorities to analyze the current } \\
\text { situation and advise them to take further } \\
\text { necessary action at field level }\end{array}$ \\
\hline 11) Project Management & $\begin{array}{l}\text { Project status information may push/pull through } \\
\text { mobile handsets. } \\
\text { Example: - Project Management } \\
\text { Employee_id: ----; Department.:---- } \\
\text { Project_id: ----; Project Status:---- } \\
\text { As on Date-:--- }\end{array}$ & $\begin{array}{l}\text { The project status information as simple } \\
\text { reports format or pictures may get directly } \\
\text { from the site on demand from the employees } \\
\text { through their mobile handsets. The experts } \\
\text { can advise employees without leaving the } \\
\text { project location. It not only saves time and } \\
\text { cost, but also provide guidance to the } \\
\text { employees at the right time. }\end{array}$ \\
\hline $\begin{array}{l}\text { 12)Location- based } \\
\text { Services }\end{array}$ & $\begin{array}{l}\text { Employees can send location-based services such as } \\
\text { field survey, crime reports, Traffic information, etc. } \\
\text { from their mobiles to the concerned department and } \\
\text { vice versa. Example: Location-based Service } \\
\text { Employe_id: --- Project_id:--- } \\
\text { Department:--- Survey Status: --- Date:--- }\end{array}$ & $\begin{array}{l}\text { Filed survey employees may send Global } \\
\text { Positioning System (GPS) based maps along } \\
\text { with reports. It is useful to the decision } \\
\text { makers, know the current status of the } \\
\text { desired service.. }\end{array}$ \\
\hline 13)Health Information & $\begin{array}{l}\text { Availability of doctors, medicines, etc. as SMS } \\
\text { notifications to the employees to know the current } \\
\text { status. } \\
\text { Example: Medicines notification } \\
\text { Employee_id:-- ; } \\
\text { Hospital_id: -- Doctor_id:--- } \\
\text { Medicines issued: ---, Date_of_issue:- }\end{array}$ & $\begin{array}{l}\text { Health related information will be available } \\
\text { to the employees on their mobiles as SMS } \\
\text { alerts. }\end{array}$ \\
\hline \multicolumn{3}{|c|}{ b) Transactional services } \\
\hline 14) Accounts Information & $\begin{array}{l}\text { SMS notifications such as Salary, Provident Fund, } \\
\text { Leave Traveling Concession, Income Taxes, } \\
\text { Deductions, Medical reimbursement, Tour advance, } \\
\text { etc. will be available to the employees. } \\
\text { Example: Salary paid notification } \\
\text { Account number:----- } \\
\text { The amount credited:--- } \\
\text { Salary/PF/LTC /T.A:-- } \\
\text { Reference no --- Date \& Time--- }\end{array}$ & $\begin{array}{l}\text { Particularly in rural/remote areas the } \\
\text { employees do not know their monthly salary } \\
\text { is credited into their accounts or not on a } \\
\text { real-time basis? The SMS alerts may give an } \\
\text { advantage to them. The employee can also } \\
\text { fill the small forms and send to the } \\
\text { concerned department. }\end{array}$ \\
\hline
\end{tabular}

